$30(66)$

\title{
CS-1：総合企画 「腎癌の診断治療」
}

\section{座長のことば}

奈良県立医科大学

平尾 佳彦

腎細胞癌は, 従来比較的少ない疾患とされてきたが, 近年の画像診断の発展・普及により偶然に診断される無症状の症例を含 めて新規診断症例数は增加している. 腎癌研究会のまとめによると, 本邦では 7000 症例以上の新規診断患者が見込まれており, その増加は小さい腎細胞癌症例の増加に起因しているが, 一方, 診断時に進行癌と診断される症例も未だ減少していない. 腎細 胞癌の治療は, 画像診断の発展により小さい腎細胞癌が多数診断されたことからその自然史が徐々に明らかになり, 早期癌に対 する患側腎温存手術が一般化すると共に，近年の分子生物学的な成果がサイトカインをはじめとする免疫療法や分子標的薬の 開発などにつながり，進行癌患者に福音をもたらしている.また, 外科治療においても周術期管理の進歩や集学的な外科治療の 展開に加えて, 体腔鏡下手術の導入や種々の低侵裝治療の発展により腎細胞癌に対する治療の概念が大きく変化してきている.

診断と治療に様々な変化がみられ選択肢が掂がると, 腎細胞癌患者にとって良い医療とは何なのか, 何が標準的な治療である のか, 臨床医にとって日常診療に多くの疑問が生じていることも事実である, 進行腎細胞癌が大半を占め, 放射線療法や化学療 法にほとんど有用性が見いだせなく, 外科的切除が唯一確実な治療であった時代を永らく経過したことから, 腎細胞癌の診断と 治療におけるいわゆるエビデンスの集積は他胹器癌に比べて極めてそしいことも事実である.

本特別企画：腎癌においては，症例呈示を基にして，我が国の腎細胞癌の診断と治療のエキスパート3名のコメントを中心 に, 会場参加者と共に日常臨床の問題となる論点に絞って討論することを目的としている.司会者として 3 名の演者には, 予め, コメントはエビデンスに基づく必要はなく,自身の経験に基づいた闊達な意見をお願いしており,アンサーチェッカーを用いた 会場参加者の意見を交えて, 明日の臨床につながる Take-a-Home Messageが 1つでも見いだせれば, 東間紘大会会長のご期待 に応えることができると考えている.

\section{CS-2：総合企画「BPH の診断治療」}

\section{座長のことば}

浜松医科大学

大園 誠一郎

今回の日泌総会の総合企画は, 東間 紘会長が, 日常の泌尿器科診療で頻度の高い疾患について, 現在の医学的水 準で何がもっとも標準的で安全な医療なのかということを,ケーススタディーを通して明らかにさせることを目的 に企画された. 本企画は, 9 領域に分かれているが，なかでも BPH はとくに頻度が高く，その診療もレジデントや 若い泌尿器科医から, 開業医, 一般病院・大学病院の泌尿器科医まで幅広い医師によって行われており, さらに, 非泌尿器科医までもがその診療に参加している現状である. 最近, 相次いで診療がイドラインが作成され，あるい は準備が進められているが, 泌尿器科領域においては, 「EBMに基づく前立腺肥大症診療ガイドライン」がもっとも 早く発刊 (2001 年)されたことは記憶に新しい。 その中で，本疾患の重症度判定にしたがって，治療指針が提示さ れ, 泌尿器科医のみならず非泌尿器科医にも対応できるようにされている. また, 治療法については, 多くの RCT から有効性の認められた方法が選択された。 しかし, 本診療ガイドラインも発刊から年月が経ち, その後も多くの RCT が報告され，また BPHにも新しい概念が含まれてきている.例えば, 2002 年にICS で取り上げられた過活動 膀胱（OAB）を合併した BPH の治療に対して, 診療ガイドラインではオプションに入っていなかった抗コリン刻 を投与する場合,一方, 診療ガイドラインで唯一エビデンスのある薬物療法として挙げられた $\alpha 1$ ブロッカーもいつ まで長期間投与するか，などなど問題症例は多く，またこれらは日常診療において遭遇する症例である．そこで， 今回, パネリストとして岡田 弘先生 (帝京大), 多森直哉先生 (札幌医大), 山口秋人先生 (原三信病院) の BPH 治療では本邦を代表する先生方にご登壇いただき，BPH 問題症例の治療指針と問題点を明らかにすることにより， 東間＼cjkstart紘会長のご要望に添いたいと考えている. 